\title{
IAMJ
}

INTERNATIONAL

AYURVEDIC

MEDICAL JOURNAL

\section{KARMASAMARTHYA (BALA): A LIFE POWER OF ALL EXISTENCE AND FACTORS FOR ITS PROMOTION BY AYURVED ASPECT}

\author{
Pradnya K. Shinde ${ }^{1}$, Pranita K. Shinde ${ }^{2}$ \\ ${ }^{1}$ Associate Professor \& HOD, Department of Kriyasharir, \\ ${ }^{2}$ Assistant Professor, Department of Swasthavritta, \\ Vidarbha Ayurved College, Amravati, Maharashtra, India
}

Corresponding Author:pshinde10673@gmail.com

https://doi.org/10.46607/iamj3508122020

(Published online: December 2020)

Open Access

(C) International Ayurvedic Medical Journal, India 2020

Article Received: 02/11/2020 - Peer Reviewed: 14/11/2020 - Accepted for Publication: 22/11/2020

(D) Check for updates

\begin{abstract}
Karmasamarthya means the ability or capacity of the person to perform work by mind, body, and speech. It can be considered as Bala or strength. Bala is an important concept of Ayurveda. It is a lifeforce of all living organisms. Ayurveda have many components to increase the Bala. This article focuses to disclose thorough review of literature of Bala and correlation of it with Bala-Vruddhikara-Bhava (factors responsible for promotion of strength) and implication towards maintenance of health. The Bala of person is governed by many factors like age, sex, food, health, disease state, time, season etc. Bala is responsible for nourishment, immunity and sustenance of life. This will boost the idea of yukti-krita promotion of Bala as an innovative powerful tool to reduce illness and hereditary disorders
\end{abstract}

Keywords: Bala, Bala-Vruddhikara-Bhava, Yukti-krita Bala,

\section{INTRODUCTION}

In the developing technological era, position of most of the physical work is taken by the machineries. So, people get rid of physical exercise, activities. As a result, their mind can run like a computer having more 
or less mental tension. But their body, strength cannot support them and so, lifestyle disorders such as obesity, stress, heart problem, diabetes mellitus, hair problems grows rapidly without any age criteria. Ayurveda Acharya before 5000 years ago mentioned the details about diet and lifestyle regimen to live healthy long life. To live quality of life you must have good strength, Bala which is described as Karmasamarthya.Ayurveda focuses on encouraging individuals to increase their strength through natural means. Ability or capacity of a person to perform all types of physical activity without any fatigue is called as Karmasamarthya i.e. physical fitness, the power to perform work. In ayurvedic literatures the synonym of Karmasamarthya used is 'Bala' so in present study we used the term Bala. Bala has been considered as the vital power, capacity, energy or force of life. The need of Bala is useful for survival, for nourishment, development, defense mechanism of body and that which helps in sustenance of life. Ayurvedic classical texts described about different types of bala among them, sharirik bala and manasika bala are most important. As mentioned in Charak samhita bala can be improved by bala vrudhhikar bhav. Bala-vruddhikara-bhava is a fundamental concept, which has a prime importance to improve Bala from the birth. Here an attempt is made to throw focus on concept of bala, its types, importance and Bala-vruddhikara-bhava.

Material \& Methods: A thorough search is done from various Ayurvedic classical texts as well as other related sources regarding the concept of bala (strength).

Literature review: Ayurveda has classified Bala into three types i.e. 1) Sahaj Bala 2) Kalaj Bala 3) Yuktikrut Bala

\section{Sahaja bala}

Sahaja-bala is one which exists in the body and mind since birth and can be correlated with constitutional strength. According to Chakrapani the constitutional strength is present in every living being from the time of birth. The sharirika and manasika bala which is attained by the healthiness of sperm \& ovum i. e. strength attained from heredity. Thus, the natural strength does not require any extraneous factor for its growth. Hence clinically it is observed that some are strong by their very nature, while others are weak either physically or mentally. These persons have a natural resistance to disease; well build body and more stable, strong mind.

\section{Kalaj Bala}

This type of Bala is stated to be influenced by seasonal traits and the age of the person. It is inclusive of the time, days, season, age and place of birth. The place having strong and healthier climate and pleasant, cool climatic conditions are kapha dominating areas i.e. belonging to Anup Desh. So people from these places have strong strength. Also, Bala is strong in early morning, spring season, and in younger age than in evening, summer and old age.

\section{Yuktikrit Bala}

It means strategies to improve Bala and can be developed by resorting to appropriate nutritional diet, vyayam and physical exercise etc. Secondly it refers to the induction of body's resistance against disese than it contributes to maintain disease- Free State of the body. Yuktikrita-Bala is achieved by the proper combination of the intake of wholesome food like pulses, rice, ghee, meat etc. and following other regimen like exercise, proper rest. It could be gained by adapting certain rules and regimens as described in Ayurved following the dincharya, ritucharya along with non suppression of Adharaniya and suppression of dharniya vega. Vyayam is a routine way to improve Bala. Rasayan therapy also acts as immunomodifier which promotes strength, and vitality to the body. Charakacharya has described Strength promoting factors as Bala vriddhikar bhava.

\section{Different Aspects of Bala}

Sushrutacharya has used the term Bala to Signify Oja, which means the finest essence of all dhatus that, is created in the body in the process of transformation of food into Dhatus. Charakacharya consider that Kapha which is one of the three basic elements of the body in its normal state of functioning represent to a vital source of strength and resistance to disease which is Bala.Shelshma in its normal state is called Bala and in abnormal state called mala \& papma (disease) 
Relation of Bala with Dosha (Kapha-dosha): Dosha i.e. Vata, pitta and kapha are in Sama avastha gives better strength to body. Bala is mentioned as function of udan vayu specifically. Kapha in normal state is known as Bala of body. Acharya Charak has described that 'Kapha' in its normal state is responsible for bala which is ultimately known as oja. Panchabhautik sanghatan of kapha mainly is Prithvi and Jala Mahabhut, regarding bala prithvi represents sthiratva, stability and Jala represent nourishment.In general normal gunas of kapha dosha are Guru guna, it facilitates anabolism and hence increases strength.Sheeta guna arrests over activity of organs and muscles thereby provide stability. Mridu guna is responsible for bringing softness to body, Snigdha guna maintains moisture and lubrication, Madhura guna is a strengthening attribute, Sthira guna provides durability and Pichila guna is responsible for binding structures and acts as protective coat. All these gunas directly indicate towards nourishment of body. So, Status of Bala is strong in Kapha prakriti and poor in Vata prakriti as compare to other.

Relation of Bala with Oja: Ayurveda also describes a unique character 'Oja' which has the strength to keep body, senses, mind and soul together in functional harmony and protects against adverse conditions in body. The excellent quality of oja induces bala due to which individual shows well- nourished fleshy body and durability, indicating healthy status of all seven dhatus, all types of movements become smooth without any obstruction, voice and complexion become pleasant and functions of external sense organs along with organs of functions are smooth.

Relation of Bala with Dhatusarata: Dhatusarata Parikshan is the important factor for assessment of Bala. It means essence, excellence or purity of dhatus. Dhatusarata is the base of physical strength where as Satvasarata is the base of mental strength. So, a person having Pravar or maximum Ashtavidha Sarata has total strength of human body at physical as well as psychological level. Among asthavidha Sarata mansa, asthi, majja, shukra Sarata have maximum Bala. Bala depends on prithvi mahabhut pradhan dhatus like mansa, asthi, majja, shukra. As Bala is rasaj bhav it also depends on rasadhatu because it primarily nourishes all other dhatus.

Significance of Bala: Due to efficacy of Bala Mansdhatu get stable and strong. Person having good Bala is able to perform any type of activity. His voice and complexion is in state of complete happiness, mind, intellect and sense organs get stimulated to perform quality work. Physiologically and socially Bala is necessary for maintaining disease free state of the body doing the acts of welfare and helping others. It developed confidence in them and thereby helped them in leading life of good citizens. To achieve this state of sharira-bala, Acharya Charaka mentioned Bala-vruddhikara-bhava.

Bala vriddhikar bhava (Factors responsible for promotion of strength)- Means and measures to develop karmasamarthya

\section{Balavat-purushe (birth from nature)}

As our body is combination of matruja-pitruja bhava therefore dominant characters of the Parents reflect in the physique. By considering this, many years ago Charaka mentions that Bala of apatya which takes birth from strong parents is always better than Bala of apatya of normal/ weak parents. So, Parents originating from Punjabi or Sindhi family are considered to be Balavana Parents.

\section{Balavat-deshe (Birth in a place where people are naturally strong.)}

It means birth in a place where people are naturally strong. Desha like Punjab, Sindha are the places which give births to the naturally strong people. Sadharana desha which is said to have balance of water and plants leads to dosha dhatu mala samyavastha and give birth to the naturally strong person.

\section{Balavat kale- (Birth at a specific time when peo-} ple naturally gain strength.)

Bala is more in sheeta rutus like Hemanta and Shishira as compared to other rutus. Charaka mentioned mainly two types of rutus -Adana kala(Shishira,Vasanta,Grishma) and Visarga Kala (Varsha,Sharada, Hemanta).In Adana kala power of sun increases day by day. Due to this penetrating power of sunrays, bala of individual decreases and in Visargakala due to dominance of sheeta moon rays, bala of 
individual increases day by day from the beginning to the end of the season; Therefore bala status is highest at the starting of Adana kala and at the ending of Visargakala. During Hemant \& shishir Ritu strength of the body is maximum i.e. November, December to January - February. During Vasant and sharad ritu strength of the body is in moderate state i.e. march April to September - Octomber. During Grishma \& varsha ritu stregth of the body is minimum i.e.mayJune to Jully -Aug.

\section{Sukhashcha-kalayoga (Favourable disposition time period)}

Favourable disposition of time includes doshadhatumala Samya avastha and sadharana kalait is balanced state of dosha, dhatu, mala in the body in visarga kala like Shishira and Hemanta rutu. Charaka mentions one important factor related to prakruti is kala garbhashaya prakruti. It means uttama prakruti forms when kala is sadharana and dosha-dhatu-mala are in samya avastha.

5. Beeja-kshetra-gunasampat (Excellenceof quality of beeja (sperm and ovum), kshetra (uterus).

It includes excellence of quality of beeja (sperm and ovum) and Kshetra - ashaya (uterus).Beeja includes excellence of Shukra (sperms) excellence of Streebeeja (ovum) as mentioned by Charakacharya.Kshetras-It includes shuddha yoni that is uterus is anatomically and physiologically well developed. As a result, healthy progeny is produced. It is stated that the progeny of parents having the excellence of sperm, ovum and uterus is endowed with strength.

\section{Ahara-sampat (Excellence of the ingested food)}

It includes excellent quality of the ingested food. Bala is achieved by proper combination

of the intake of wholesome food like kshira, dadhi, navneeta, ghruta, rakta-shali, mudga-yusha, saindhava, amalaki, yava, mansa-rasa, madhu etc. The food having madhur, amla, lavana rasa, having snigdha, sheet, guru gunas also useful to restore physical strength. Following other regimen like proper rest, exercise and appropriate use of rasayana-yoga is helpful to maintain Bala.

\section{Sharira-sampat (Excellence of physique)}

It includes excellence of physique.Charakacharya mentioned that Sama-mansa, Sama-pramana which is measured by individual fingers, hands etc. in terms of height, breadth \& length respectively, Samasamhanana (Compactness) a well compact body is known by evenly well demarcated bones, well bound joints, well formed muscle \& blood.Those who have well compact body are strong, will be able to tolerate heat-cold-hunger-thirst-vyayama, will be having samyaka-pachana and jaranashakti.

8. Satmya-sampat (Excellence of suitability) (wholesomeness of various factors responsible for the maintenance of the body)

It means suitability, adapting to wholesome substance $\&$ giving up unwholesome substance to which the physiology has been addicted since birth. With the abhyasa-satmya of any specific substance anyone can make that substance adoptable to them. It means the various foods, Rasa, habits, customs etc used by people for long periods of time by continuous use \& not getting harmed from them. A good or pravar satmaya person has good strength, develop ability to take any taste, any type of medicine.

\section{Satva-sampat (Excellenceof intellect and mind.)}

It includes excellence of intellect and mind. It is believed that it regulates the body because of its association with the soul. Individuals having superior mental abilities are called as satvasara purusha. Such person possesses excellence in mental abilities even if have weak physique. Such person because of specific manifestation of satva can tolerate sereious exogenous and endogenus activities without much difficulty. Also, can be able to tolerate different type of disease states.

10. Svabhava-samsiddhi (Favourable disposition of nature)

Bala is one which exists in the body and mind since birth. According to Charaka prakriti arambhak bhava are responsible factors for the formation of prakriti of individual. On the basis of these factors' person is developed with particular dosha dominant constitution, which remains constant.

\section{Youvana (Youthfulness)}

Every individual in his young age has more strength. It includes youthfulness that is madhyamavaya (from 
30-60 yrs of age). According to Charaka Vaya is mainly of three types Baala, Madhyama and Vruddha. The Bala in adulthood will be more; compared to childhood and old age. Madhyamaavastha of vaya includes, qualities of all dhatus having reached the normal limit, with proper physical and mental strength, without degeneration in qualities of dhatus, having predominance of Pitta dosha.

\section{Karma (exercise)}

Vyayamshakti Parikshan is a good source to assess Bala. The physical activity of the body which is desirable to mind and provide stability to the body \& improves Bala of the body is called as vyayam or exercise. Vyayam gives hormony to the body of mind, strength to the muscles \& tendons. It liberates the spinal coloumn \& gives the necessary elasticity. Doing exercise is a very good standard to timprove Bala. But it should be taken in right measure $\&$ should be increased gradualty. There is reference about at what time one should have exercise in ashtang hriday sutrasthan. It should be taken to the half exert of ones own capcity. To reduce stress or strain of the human body \& mind there is need of vyayam in daily life.

\section{Sauharsha- (Cheerful disposition)}

Person with prasanna-atma, indriya and mana is called as swastha. That is person with happy mind state have ability to tolerate any type of physical and mental disorders. In this way happiness promotes strength.

\section{DISCUSSION}

Bala plays a very important role in swastha and atura avastha of sharira. Bala is basic characteristic of prakrut kapha dosha and vaat dosha i.e. prakrut udan vayu. Prakrita kapha mainly protects the body by preventing it from the wear and tear process. An individual with kapha dominant prakriti has excellent strength. Oja is considered to be the upmost component of vitality along with that it provides physical and mental resistance against diseases i.e. vyadhikhaamatva. Bala is the attribute of excellence of mansa, asthi, majja, shukra and sarva dhatusarata. Individual having Sama samhat sharira is called as Balawant. After thorough review of literarture of Bala and Bala-
Vruddhikara-Bhava, promotion of the strength of a person from the birth is possible, because if parents should plan their conception as per ritu as in visarga kala, can follow ahar-vihar as mentioned in texts, having excellent desha of birth, place of deleivery. If one can follow this perfectly then result of progeny is definitely Balwan, having good strength. All thirteen factors mentioned as Bala-Vruddhikara-Bhava's can be included in-Sahaja, Kalaja and Yuktikruta Bala.Classification of this can be done as Sahajabala includes balavat-purushe, balavat-deshe, balavatkale, beejakshetra-sampat, satva, satmya-sampat, and svabhava -samsiddhi. They are useful to improve immunity. Kalaja-Bala includes balavat-kale, yauvana, sukhascha-kalayoga. Yuktikruta-Bala includes aahara-sharirasatmya- sampat, youvana, karma, sauharsha.

\section{CONCLUSION}

From this study it can be concluded that to maintain health and to prevent the diseases Bala is an essential factor. With the help of Bala-vruddhikara-bhava, we can promote physical and mental fitness to fight with diseases and improves quality of genes which prevent genetic disorders. This Bala is mainly obtained by certain components in body viz. Prakrita kapha, Oja, and Sarawan dhatu. Nourishment of dhatu leads to increase in physical strength and stability of body. Applicability of bala vruddhikar bhava will pramote our strength which brings about pleasure of mind. If the person having ability to work is normal then all the functions work properly i.e. digestion, respiration, circulation, etc and the person can lead a healthy life. Bala could be achieved by adopting Bala-VruddhikarBhava, by taking proper ahara, vihar, dincharya, rirtucharya, sadvritta, vyayam, and rasayana therapy. Maintenance of tridosha and sapta dhatu is also essential to achieve the Bala or strength. The person having all these qualities is said to be Balawan or having good karmasamarthya. 


\section{REFERENCES}

1. Agnivesha, Charaka Samhita, Vimanasthan, Ch.8/96, Edited by AcharyaYadavji Trikamji, Reprint ed. Varanasi: Chaukhamba Surbharti Prakashan; 2014.

2. Sushruta, Sushruta Samhita, Sutra Sthana, Ch. 15, Edited by AcharyaYadavji Trikamji, Reprint ed. Varanasi: Chaukhamba Surbharti Prakashan.

3. Acharya Yadavji Trikamji, editor. CharakaSamhita of Agnivesha, Sutra Sthana, Ch. 21, Reprint ed. Varanasi: Chaukhamba Surbharti Prakashan; 2014.

4. Acharya YadavjiTrikamji, editor. Charaka Samhita of Agnivesha, Sharira Sthana, Ch. 6, Reprint ed. Varanasi: Chaukhamba SurbhartiPrakashan;2014.

5. Acharya Yadavji Trikamji, editor. Charaka Samhita of Agnivesha, Sharira Sthana, Ch. 6, Chakrapani commentary, Reprint ed. Varanasi:C haukhamba Surbharti Prakashan; 2014.

6. Acharya Yadavji Trikamji, editor. Charaka Samhita of Agnivesha, Sharira Sthana, Ch.4, Reprinted. Varanasi: Chaukhamba Surbharti Prakashan; 2014.

7. R. K. Sharma Bhagwan Dash, editor. Charaka Samhita of Agnivesha, Chikitsa Sthana, Ch.30, Vol.5. Text with English translation, Reprint ed. Varanasi: Chaukhamba Surbharti Prakashan; 2001.

8. Vriddha Vagbhat, Ashtang-Samgraha with Shashilekha commentary by Indu, edited by Dr. Shivprasad Sharma, Chaukhamba Sanskrit Series Office, Varanasi (India), 2nd edition-2008.

\section{Source of Support: Nil \\ Conflict of Interest: None Declared}

How to cite this URL: Pradnya K. Shinde \& Pranita K. Shinde: Karmasamarthya (Bala): A Life Power Of All Existence And Factors For Its Pro-motion By Ayurved Aspect. International Ayurvedic Medical Journal \{online\} 2020 \{cited December, 2020\} Available from: http://www.iamj.in/posts/images/upload/5399 5404.pdf 